\title{
THE
}

7-13-2018

\section{Development of Electrolytes for Si-Graphite Composite Electrodes}

\author{
Cao Cuong Nguyen \\ University of Rhode Island \\ Brett L. Lucht \\ University of Rhode Island, blucht@chm.uri.edu
}

Follow this and additional works at: https://digitalcommons.uri.edu/chm_facpubs

Creative Commons License

\section{(c) (1)}

This work is licensed under a Creative Commons Attribution 4.0 License.

\section{Citation/Publisher Attribution}

Nguyen, C.C., Lucht, B.L. Development of electrolytes for Si-graphite composite electrodes (2018) Journal of the Electrochemical Society, 165(10), pp. A2154-A2161. DOI: 10.1149/2.0621810jes

Available at: http://dx.doi.org/10.1149/2.0621810jes

This Article is brought to you for free and open access by the Chemistry at DigitalCommons@URI. It has been accepted for inclusion in Chemistry Faculty Publications by an authorized administrator of DigitalCommons@URI. For more information, please contact digitalcommons-group@uri.edu. 


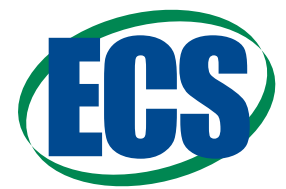

\title{
Development of Electrolytes for Si-Graphite Composite Electrodes
}

\author{
Cao Cuong Nguyen and Brett L. Lucht $\oplus^{*, z}$ \\ Department of Chemistry, University of Rhode Island, Kingston, Rhode Island 02881, USA
}

The performance of Si-graphite/Li cells and Si-graphite/NMC111 cells has been investigated in 1.2 M LiPF $/$ EC:DEC (1/1, w/w) with different electrolyte additives including $\mathrm{LiNO}_{3}, \mathrm{FEC}$, and MEC. The addition of additives into electrolytes result in a significant improvement in capacity retention compared to the standard electrolyte for Si-graphite/Li cells. The cells cycled with electrolyte containing $0.5 \mathrm{wt} \% \mathrm{LiNO}_{3}, 5-10 \mathrm{wt} \%$ MEC or $10 \mathrm{wt} \% \mathrm{FEC}$ have high capacity retention, at least $88 \%$, while the cells cycled with standard electrolyte have lower capacity retention, $64 \%$, after 100 cycles. Investigation of Si-graphite/NCM111 cells reveals that the cells cycled in electrolyte containing $0.5 \mathrm{wt} \% \mathrm{LiNO}_{3}$ have better capacity retention than cells cycled with $10 \mathrm{wt} \% \mathrm{FEC}, 57.9 \%$ vs. $44.6 \%$, respectively. The combination of $10 \% \mathrm{MEC}$ and $\mathrm{LiNO}_{3}$ further improves the capacity retention of the Si-graphite/NCM111 full cells to $79.9 \%$ after 100 cycles which is highest among the electrolytes investigated. Ex-situ surface analyses by XPS and IR-ATR have been conducted to provide a fundamental understanding the composition of the solid-electrolyte interphase (SEI) and its correlation to cycling performance.

(C) The Author(s) 2018. Published by ECS. This is an open access article distributed under the terms of the Creative Commons Attribution 4.0 License (CC BY, http://creativecommons.org/licenses/by/4.0/), which permits unrestricted reuse of the work in any medium, provided the original work is properly cited. [DOI: 10.1149/2.0621810jes]

(cc) BY

Manuscript submitted April 4, 2018; revised manuscript received June 28, 2018. Published July 13, 2018.

Si has been intensively investigated as anode material for lithium ion batteries due to its high theoretical capacity, $3579 \mathrm{mAh} / \mathrm{g} .{ }^{1-5} \mathrm{How}-$ ever, the cycle life of $\mathrm{Si}$ is much worse than commercial graphite anodes due to the large volume change of $\mathrm{Si}(\sim 280 \%)$ upon lithiation which results in particle pulverization, ${ }^{1-5}$ loss of electrical connection within electrode components, ${ }^{1-6}$ and continuous decomposition of the electrolyte. ${ }^{7-11}$ The cycling performance of silicon has been improved by using nano-structured silicon which better tolerates the large volume changes of silicon upon lithiation/delithiation. ${ }^{2,4,5,12}$ Further improvement has been obtained by using $\mathrm{Si} /$ graphite composite electrodes since graphite improves the electrical contact and accommodates the volume change of $\mathrm{Si}$. Si/graphite composite electrodes can also be calendared to obtain higher loading density and further improves electrical contact between particles. ${ }^{13,14}$ Other methods to impove the cycling performance of silicon based electrodes include the use of sacrificial electrolyte additives to form a stable solid electrolyte interphase (SEI) on the silicon particles. Vinylene carbonate (VC) and fluoroethylene carbonate (FEC) are the most frequently used additives in carbonate based electrolytes for silicon electrodes. ${ }^{7,9,15}$ These additives are reduced to form a stable SEI composed of polycarbonate, lithium alkyl carbonates, $\mathrm{Li}_{2} \mathrm{CO}_{3}$ and $\mathrm{LiF}^{9}{ }^{911}$ However, recent investigations suggest that high concentrations of FEC increase the reactivity of the electrolyte with lithiated graphite resulting in capacity loss upon storage. ${ }^{16}$ The high concentration of FEC also causes significant gas evolution in $\mathrm{Si}$-graphite/ $\mathrm{LiCoO}_{2}$ full cells compared to electrolytes containing VC. ${ }^{10,17} \mathrm{Kim}$ et al. ${ }^{18}$ reported that FEC decomposes at elevated temperature to produce HF which causes SEI degradation and transition metal ion dissolution from the cathode. Development of alternative additives to FEC is necessary. Recently, we reported that the cyclability of silicon electrodes was signiciantly improved by inclusion of methylene ethylene carbonate (MEC). ${ }^{19}$ The SEI on Si cycled with electrolyte containing MEC has a high concentration of polycarbonate (i.e., poly(MEC)) and lithium carbonate. Lithium nitrate has been widely investigated as an additive for $\mathrm{Li} / \mathrm{S}$ batteries since it can be reduced on the surface of lithium to form a SEI which passivates the surface of the lithium anode. ${ }^{20-25}$ Aubach and co-authors reported that silicon electrodes cycled with 1 M LiTFSI in an ether based electrolyte with added lithium nitrate has significantly improved cycling performance. ${ }^{26}$ However, the use of ether based electrolytes limits the choice of cathode materials due to the oxidative instability of ethers at the cathode surface at high voltage. In addition, there have been no reports on the use of $\mathrm{LiNO}_{3}$ as an additive for Si-based anodes in alkyl carbonate based electrolytes, possibly due to the low solubility of $\mathrm{LiNO}_{3}$ in carbonate solvents.

\footnotetext{
*Electrochemical Society Member.
}

${ }^{\text {z} E-m a i l: ~ b l u c h t @ c h m . u r i . e d u ~}$
In this report, a combination MEC or FEC with $\mathrm{LiNO}_{3}$ have been investigated as electrolyte additives for $\mathrm{Si} /$ graphite composite electrodes. A significant reduction in capacity fade over 100 cycles is observed for Si-graphite/lithium cells with electrolytes containing the additives. The novel electrolyte formulations also improve the cycling performance of Si-graphite/NCM111 cells. In addition, the surface of the cycled electrodes have been investigated via a combination of attenuated total reflectance infrared spectroscopy (ATR-IR) and X-ray photoelectron spectroscopy (XPS) to develop a better understanding of the role of the additve in SEI structure and fucntion.

\section{Experimental}

Silicon nanoparticles $(\leq 50 \mathrm{~nm})$ were purchased from Alfa Aesar. Super C65 and SFG6L graphite was provided by Timcal and G8 graphite was provided by ConocoPhillips. Partially neutralized PAA was prepared by reaction of poly (acrylic acid) (PAA, $\mathrm{M}_{\mathrm{w}}=450,000$, Aldrich) with $\mathrm{LiOH}$ with a mole ratio of PAA/LiOH of 0.7 (denoted as $\mathrm{PAALi}_{0.7}$ ). The $\mathrm{pH}$ of diluted solution of PAALi $\mathrm{P}_{0.7}$ was $\sim 6.5$. $^{27}$ Silicon nanoparticles, SFG6L and G8, super C and PAALi with a ratio of 10:45:30:5:10 (in weight) were thorough mixed in distilled water with a mortar and pestle for 1 hour then stirred for additional 3 hours with a magnetic stirring bar. The composite electrode formulation was determined from preliminary experiments to optimize capacity and cycle life. The well mixed slurry was spread on copper foil and dried at room temperature in air for one hour and then in a vacuum oven overnight. The anode electrodes were then punched into $14.0 \mathrm{~mm}$ diameter disks and dried at $120^{\circ} \mathrm{C}$ in a vacuum oven overnight. The electrodes were not calendared and have a loading of $1.2 \mathrm{mAh} / \mathrm{cm}^{2}$. The cathodes were prepared by coating a slurry consisting of $90 \mathrm{wt} \%$ $\mathrm{LiMn}_{1 / 3} \mathrm{Ni}_{1 / 3} \mathrm{Co}_{1 / 3} \mathrm{O}_{2}$ (NMC111) (BASF), 5 wt $\%$ super $\mathrm{C}$ (Timcal) and $5 \mathrm{wt} \%$ poly(vinylene difluoride) (PVdF, Solvay) in N-methyl-2pyrrolidone solvent onto aluminum foil. The cathode electrodes were cut into $13.7 \mathrm{~mm}$ diameter disks and dried at $120^{\circ} \mathrm{C}$ in a vacuum oven overnight. The N/P ratio in full cells is $\sim 1.1$.

Electrolyte solvents, salts and additives were obtained from BASF and used as received. The water content is $<50 \mathrm{ppm}$. 2032 coin cells consisting of a Si-graphite working electrode, a lithium foil counter electrode, $100 \mu \mathrm{L}$ electrolyte and two separators (one Celgard 2325 and one Whatman GF/D glass fiber) were prepared (half cells). 2032 coin cells were also prepared with a Si-graphite anode, a NCM111 cathode, one Whatman GF/D glass fiber between two Celgard 2325 separators and $100 \mu \mathrm{L}$ electrolyte (full cells). The standard electrolyte was 1.2 $\mathrm{M} \mathrm{LiPF}_{6} /$ ethylene carbonate (EC): diethyl carbonate (DEC) $(1: 1, w / w)$. MEC, FEC and $\mathrm{LiNO}_{3}$ were added to the standard electrolyte by weight percentage. Details about electrolyte formulations are provided in Table I. The half cells were charged (lithiation) and 
Table I. Electrolyte formulations investigated.

Electrolyte

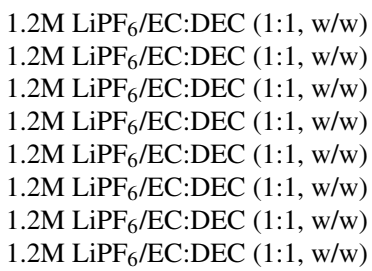

Additive concentration

Saturated $\mathrm{LiNO}_{3}(\sim 0.5$ wt $\%, \sim 0.09 \mathrm{M})$
$5 \%$ wt MEC
$10 \%$ wt MEC
$10 \%$ wt.FEC
$10 \%$ wt.FEC $+0.5 \%$ wt. $\mathrm{LiNO}_{3}$
$5 \%$ wt.MEC+0.5\% wt. $\mathrm{LiNO}_{3}$
$10 \%$ wt.MEC $+0.5 \%$ wt. $\mathrm{LiNO}_{3}$

discharged (delithiation) between 0.005 and $1.5 \mathrm{~V}$ with constant current and constant voltage (CC-CV) at a rate of $\mathrm{C} / 20$ for first cycle and at the rate of $\mathrm{C} / 3$ for an additional 99 cycles using an Arbin BT2000 battery cycler at $25^{\circ} \mathrm{C}$. At the end of lithiation, the cells were held at $5 \mathrm{mV}$ until the current decreased to $\mathrm{C} / 20$. The rate was calculated based on a capacity of the Si-graphite electrode of $630 \mathrm{mAh} / \mathrm{g}$ (total weight including binder) which was obtained using the theoretical capacity of $\mathrm{Si}(3579 \mathrm{mAh} / \mathrm{g})$ and graphite $(372 \mathrm{mAh} / \mathrm{g})$. The full cells were cycled with same rate as in half cells but in the voltage window of 2.5-4.2 V. The capacity of full cells was calculated based on mass of the cathode active material. All cells were built in duplicate.

Cycled electrodes were extracted from cells after the $100^{\text {th }}$ discharge, carefully rinsed with DMC four times $(1 \mathrm{~mL}$ in total) to remove residual electrolytes and then dried in an argon-filled glove box for ex-situ surface analysis. The infrared spectra with attenuated total reflectance (IR-ATR) were measured with 256 scans and spectral resolution of $4 \mathrm{~cm}^{-1}$ using Bruker Tensor 27 equipped with LaDTG detector inside a nitrogen-filled glove box. Samples were transferred in an argon filled jar. Surface analysis was conducted using ex-situ XPS (K-alpha, Thermo) with $\mathrm{Al} \mathrm{K}_{\alpha} \mathrm{X}$-ray source at a pass energy of $50 \mathrm{eV}$ and a measured spot size of $400 \mu \mathrm{m}$ without charging compensation. The electrodes were transferred from the glove box to the XPS analysis chamber using a special vacuum-sealed module (Thermo) without exposure to air. The binding energy was corrected based on the $\mathrm{C} 1 \mathrm{~s}$ peak of hydrocarbon at $285 \mathrm{eV}$.

\section{Results and Discussion}

Performance of silicon-graphite/Li half cells._Electrochemical performance.-The voltage vs capacity profiles of Si-graphite/Li half cells for first cycle in different electrolytes are provided in Figure 1a. The first discharge capacity, initial coulombic efficiency and capacity retention are presented in Table II. All electrodes have a similar delithiation capacity of $\sim 600 \mathrm{mAh} / \mathrm{g}$ based on the weight of the entire composite electrodes, excluding the weight of coper current collector. The capacity is $\sim 700 \mathrm{mAh} / \mathrm{g}$ based on weight of the active materials,
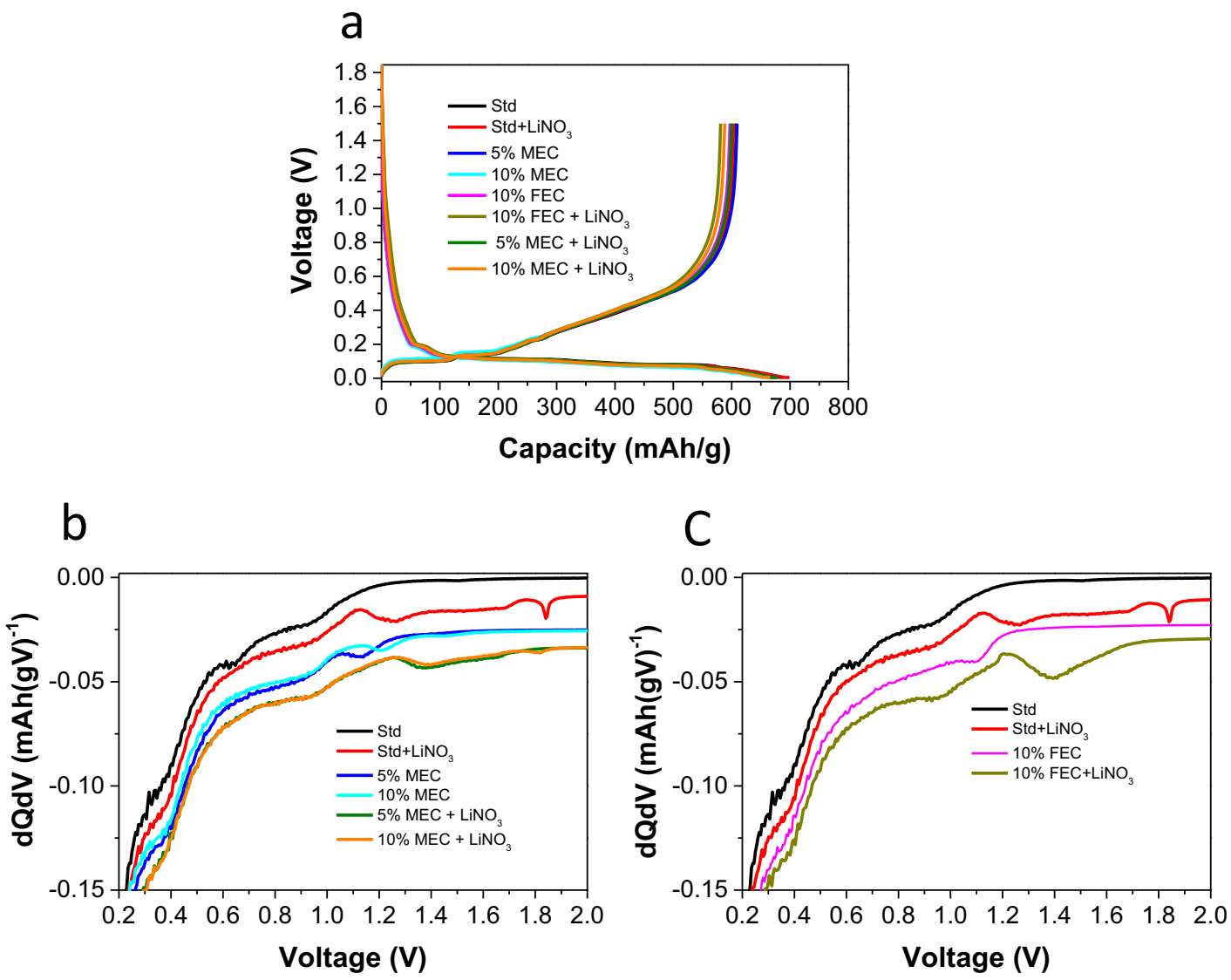

Figure 1. Voltage profile plots for the first cycle (a), dQ/dV plots ( $b$ and c) for the first charge in region of $0.2 \mathrm{~V}$ to $2 \mathrm{~V}$. The curves in $\mathrm{dQ} / \mathrm{dV}$ are plotted offset in Y-axis to avoid the overlap between curves. 
Table II. First discharge capacity, first cycle efficiency and capacity retention (average of duplicate cells) of Si-graphite/Li half cells. Capacity retention was calculated compared to the $2^{\text {nd }}$ discharge capacity of the cells where the cells were cycled at same rate, $\mathrm{C} / 3$, for cycles $2-100$.

\begin{tabular}{cccc} 
& First discharge capacity $(\mathrm{mAh} / \mathrm{g})$ & First cycle Efficiency $(\%)$ & 100 $^{\text {th }}$ capacity retention $\left(\%\right.$, calculated against $2^{\text {nd }}$ discharge $)$ \\
\hline Std & 609 & 88.6 & 64.0 \\
Std+LiNO & 601 & 87.0 & 89.3 \\
$5 \% \mathrm{MEC}$ & 602 & 89.9 & 88.3 \\
$10 \% \mathrm{MEC}$ & 596 & 90.1 & 88.2 \\
$10 \% \mathrm{FEC}$ & 599 & 88.5 & 88.4 \\
$10 \% \mathrm{FEC}+\mathrm{LiNO}_{3}$ & 581 & 86.0 & 94.2 \\
$5 \% \mathrm{MEC}+\mathrm{LiNO}_{3}$ & 598 & 88.1 & 93.5 \\
$10 \% \mathrm{MEC}+\mathrm{LiNO}_{3}$ & 600 & 88.4 & 92.8
\end{tabular}

$\mathrm{Si}$ and graphite. The $\mathrm{dQ} / \mathrm{dV}$ plots for first lithiation in the region of $2.0-0.2 \mathrm{~V}$ are provided in Figure $1 \mathrm{~b}$ and $1 \mathrm{c}$. The $\mathrm{dQ} / \mathrm{dV}$ plots for the first lithiation for cells cycled with standard electrolyte exhibit shoulders at $\sim 0.93$ and $0.63 \mathrm{~V}$ due to the reduction of EC and DEC. ${ }^{28}$ The cell cycled with $10 \%$ FEC contains a small new peak around $1.1 \mathrm{~V}$, attributed to the reduction of FEC. The cell cycled with added MEC contains a new peak at $1.1-1.2 \mathrm{~V}$, which is due to the reduction of MEC, as previously reported. ${ }^{19,29}$ The cells cycled with added $\mathrm{LiNO}_{3}$ shows several peaks from 1.9-1.2 $\mathrm{V}$, attributed to the reduction of $\mathrm{LiNO}_{3}{ }^{30}$ The cell cycled with a combination of FEC and $\mathrm{LiNO}_{3}$ contains a peak centered at $1.4 \mathrm{~V}$ and a shoulder from $0.7-1.2 \mathrm{~V}$, attributed to reduction of FEC and EC and/or DEC. The electrodes cycled with a combination of MEC and $\mathrm{LiNO}_{3}$ also show a peak centered at $\sim 1.4 \mathrm{~V}$, probably due to the reduction of $\mathrm{LiNO}_{3}$. Interestingly, the small peaks for the reduction of MEC at around $1.2 \mathrm{~V}$ disappear. The presence of $\mathrm{LiNO}_{3}$ appears to alter the reduction mechanism of both FEC and MEC.

The capacity retention of Si-graphite electrodes in half cells with different electrolytes is provided in Figure 2. The electrodes cycled with the standard electrolyte have rapid capacity fade to $64.0 \%$ after 100 cycles (Figure $2 \mathrm{a}$ and Table II). The first cycle efficiency is $88.6 \%$ (Table II). The addition of FEC to the standard electrolyte improves capacity retention to $\sim 88.4 \%$ after 100 cycles. The cells cycled with electrolyte containing added MEC (5 and 10\%) have similar capacity retention to the cell containing $10 \mathrm{wt} \% \mathrm{FEC}$, but have better first cycle efficiency, $\sim 90 \%$ compared to $88.5 \%$ for the cell cycled with $10 \%$ FEC. Surprisingly, the addition of $\sim 0.5 \% \mathrm{LiNO}_{3}(\sim 0.09 \mathrm{M})$ into the standard electrolyte improves capacity retention of the cells to $89.3 \%$ after 100 cycles which is comparable to the cells cycled with electrolyte containing $10 \%$ FEC or 5 or $10 \%$ MEC. However, the first cycle efficiency is $87.0 \%$ which is lower than observed for the cells cycled with added FEC or MEC. The lower first cycle efficiency is probably due to the significant reduction of $\mathrm{LiNO}_{3}$ as observed in the $\mathrm{dQ} / \mathrm{dV}$ plots in Figure 1b. Interestingly, cells cycled with a combination of $\mathrm{LiNO}_{3}$ with MEC or FEC further improve the capacity retention to $\sim 93 \%$ despite having slightly lower first cycle efficiency compared to the cells cycled with only MEC or FEC. This data suggests a synergic effect of the combination MEC or FEC and $\mathrm{LiNO}_{3}$.
SEI formation on silicon-graphite anode in half cells.-IR-ATR spectra of the Si-graphite anodes before and after 100 cycles in half cells are provided in Figure 3. The fresh electrode contains peaks at 1700 and $1552 \mathrm{~cm}^{-1}$, attributed to carboxylic acid $(-\mathrm{COOH})$ and carboxylate (-COOLi) functional groups from partially lithiated PAA binder, the PAALi ${ }_{0.7}{ }^{27}$ Absorptions are also observed at 1583 and $869 \mathrm{~cm}^{-1}$ characteristic of graphite. ${ }^{31,32}$ After 100 cycles with the standard electrolyte, the Si-graphite electrode contains strong absorptions characteristic of electrolyte decomposition products. The absorptions at 1652,1319 and $822 \mathrm{~cm}^{-1}$ are characteristic of lithium alkyl carbonates, ROCOOLi, ${ }^{8,9,15,31,33,34}$ while the absorption at 1450 and $1490 \mathrm{~cm}^{-1}$ are characteristic of lithium carbonate, $\mathrm{Li}_{2} \mathrm{CO}_{3} .8,9,15,31,33,34$ The electrode cycled with electrolyte containing added $\mathrm{LiNO}_{3}$ contains similar electrolyte decomposition products to the electrolyte cycled in standard electrolyte. The IR spectrum of the Si-graphite electrode cycled with 5\% MEC show a strong peak at $1802 \mathrm{~cm}^{-1}$, from poly(MEC) ${ }^{19,29}$, and at 1490,1450 and $869 \mathrm{~cm}^{-1}$ from $\mathrm{Li}_{2} \mathrm{CO}_{3}$. The presence of lithium carboxylate, RCOOLi is suggested by the presence of a weak absorption at $1613 \mathrm{~cm}^{-1} .35$ Increasing the concentration of MEC to $10 \%$ increases the intensity of the peak at 1802 $\mathrm{cm}^{-1}$, suggesting a higher concentration of poly(MEC).${ }^{19,29}$ Interestingly, the electrodes cycled in a combination of $\mathrm{MEC}$ and $\mathrm{LiNO}_{3}$ have very different IR-ATR spectra compared to electrodes cycled either in MEC or $\mathrm{LiNO}_{3}$ alone. The spectra of the electrodes cycled with $\mathrm{MEC}+\mathrm{LiNO}_{3}$ are dominated by peaks at 1490, 1450 and 869 $\mathrm{cm}^{-1}, 8,9,15,31,33,34$ suggesting that $\mathrm{Li}_{2} \mathrm{CO}_{3}$ is the main component of the SEI. Surprisingly, the peak for poly(MEC) at $1802 \mathrm{~cm}^{-119,29}$ is weak, consistent with a low concentration of poly(MEC) in the SEI. The absorption characteristic of ROCOOLi at $1652 \mathrm{~cm}^{-1}$ is very weak consistent with an absence of ROCOOLi. It appears that $\mathrm{LiNO}_{3}$ inhibits the formation of poly(MEC) and promotes the formation of $\mathrm{Li}_{2} \mathrm{CO}_{3}$ on surface of Si-graphite anodes. The spectra of Si-graphite electrodes cycled with the $10 \%$ FEC electrolyte and the $10 \%$ FEC $+\mathrm{LiNO}_{3}$ electrolyte are similar to each other and are dominated by $\mathrm{Li}_{2} \mathrm{CO}_{3}$. However, additional peaks are observed at $1615 \mathrm{~cm}^{-1}$ for lithium carboxylate salts, RCOOLi, and $1802 \mathrm{~cm}^{-1}$ for poly(FEC). The high concentration of $\mathrm{Li}_{2} \mathrm{CO}_{3}$ in cells containing FEC is likely

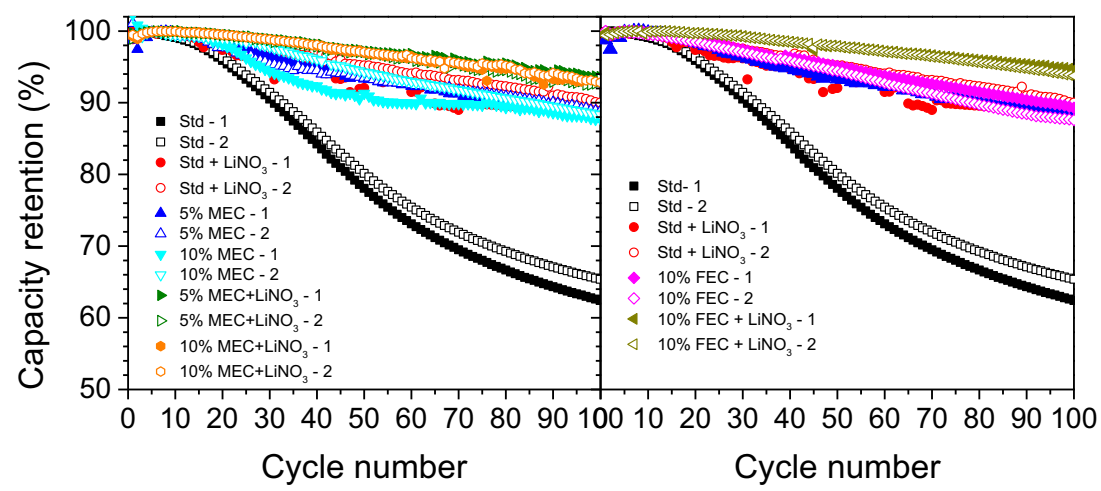

Figure 2. Capacity retention of Si-graphite electrodes from Si-graphite/lithium cells with different electrolytes. 


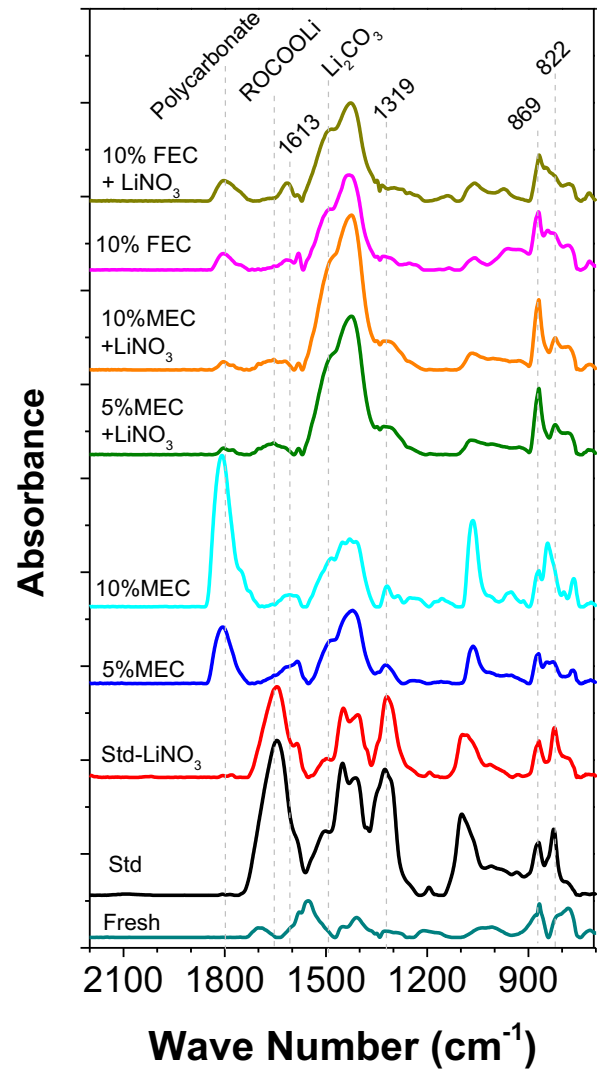

Figure 3. ATR-IR of the Si-graphite anodes extracted from Si-graphite/Li half cells after 100 cycles.

related to the generation of $\mathrm{Li}_{2} \mathrm{CO}_{3}$ upon reduction of $\mathrm{FEC}$ as previously reported. ${ }^{36}$

Performance of silicon-graphite/NCM111 full cells.Electrochemical performance.-Since Si-graphite anodes have promising cyclability with electrolytes containing a combination of $\mathrm{MEC}$ and $\mathrm{LiNO}_{3}$, Si-graphite/NCM111 cells have been investigated with this interesting electrolyte. Cycling data of the Si-graphite/NCM111 cells are depicted in Figures 4 and 5. The cycling performance of Si-graphite/NMC111 with electrolytes containing added $\mathrm{LiNO}_{3}$ or FEC is also included for comparison. The first cycle discharge capacity and efficiency for cells containing the different electrolytes are listed in Table III. The cells cycled with standard electrolyte have an initial discharge capacity of 141.8 $\mathrm{mAh} / \mathrm{g}$ and a first cycle efficiency of $83.1 \%$ (Figure 5 and Table III). However, the capacity fades rapidly over 100 cycles. The capacity retention is significantly improved when additives are added to the electrolytes. The cells cycled with $10 \mathrm{wt} \%$ FEC have a significant improvement in capacity retention compared to standard electrolyte $(44.6 \%$ vs. $8.8 \%)$. Interestingly, the cells cycled with electrolyte containing std $+\mathrm{LiNO}_{3}$ have better capacity retention compared to the cells cycled in $10 \%$ FEC. After 100 cycles, the cells containing std $+\mathrm{LiNO}_{3}$ retain $57.6 \%$ of the initial capacity. The cells cycled with $10 \% \mathrm{FEC}+\mathrm{LiNO}_{3}$ have better performance than the cells cycled with $10 \%$ FEC alone but are similar to std $+\mathrm{LiNO}_{3}$ with a lower first cycle efficiency. Si-graphite/NCM111 full cells containing electrolyte with added $\mathrm{MEC}+\mathrm{LiNO}_{3}$ have the best electrochemical performance. The cells cycled with $10 \% \mathrm{MEC}+\mathrm{LiNO}_{3}$ have high capacity retention of $79.9 \%$ after 100 cycles.

Surface characterization of cycled electrodes in silicongraphite/NCM111 full cells.-Surface chemistry of the Si-graphite anode.-The surface of the Si-graphite anodes cycled in different electrolytes in full cells, has been investigated via IR-ATR and XPS.
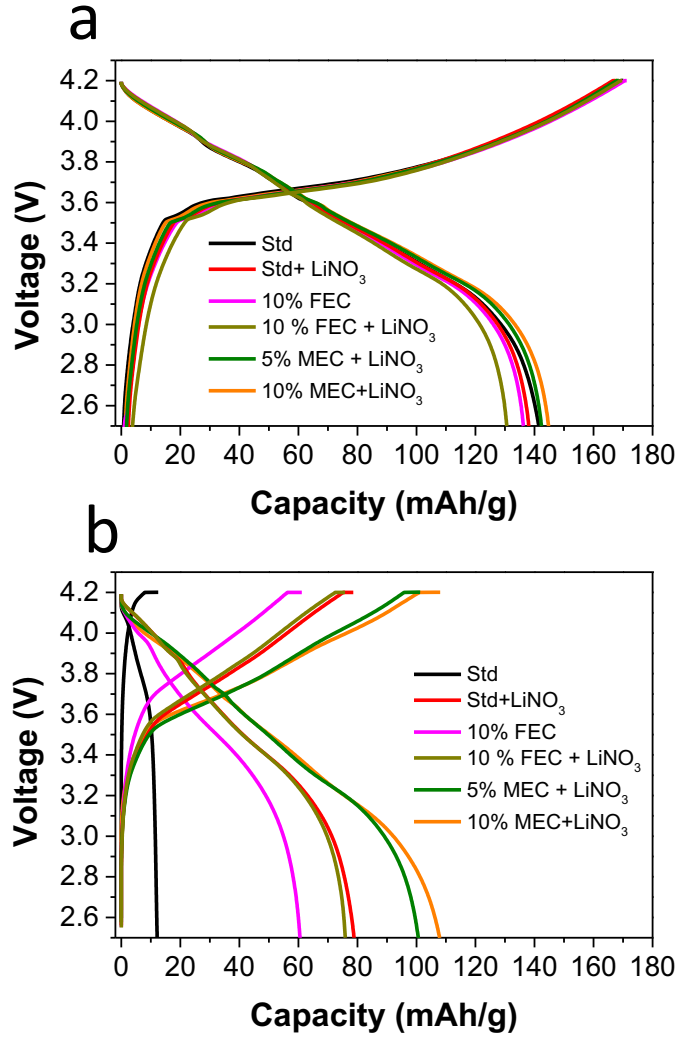

Figure 4. Voltage profiles for the first (a) and $100^{\text {th }}$ cycle (b) of Sigraphite/NCM111 full cells with different electrolytes.

The IR-ATR spectra of Si-graphite anodes before and after cycling in Si-graphite/NMC111 full cells are presented in Figure 6. The IR spectrum of Si-graphite electrode cycled with the standard electrolyte is similar to the electrode cycled in a half cell and is dominated by lithium alkyl carbonates, ROCOOLi, at 1652, 1319 and 822 $\mathrm{cm}^{-1}, 8,9,15,31,33,34$ and lithium carbonate, $\mathrm{Li}_{2} \mathrm{CO}_{3}$, at 1490,1450 and $869 \mathrm{~cm}^{-1} .8,9,15,31,33,34$ The cell cycled in $\mathrm{Std}+\mathrm{LiNO}_{3}$ contains strong absorptions characteristic of $\mathrm{Li}_{2} \mathrm{CO}_{3}$ at 1490 and $1450 \mathrm{~cm}^{-1}$ and a weaker peak characteristic of ROCOOLi at $1652 \mathrm{~cm}^{-1}$ which is different than the spectra observed for the Si-graphite half cells. The spectra of the cells cycled in $\mathrm{MEC}+\mathrm{LiNO}_{3}$ are dominated by absorptions characteristic of $\mathrm{Li}_{2} \mathrm{CO}_{3}$ at 1490,1405 and $869 \mathrm{~cm}^{-1}$, similar to observation in half cells. However, the peak at $1802 \mathrm{~cm}^{-1}$, characteristics of poly(MEC) is weaker compared to the spectra of the electrodes cycled in half cells (Figure 3). The electrodes cycled with $10 \%$ FEC and $10 \%$ FEC+ $\mathrm{LiNO}_{3}$ show similar spectra to each

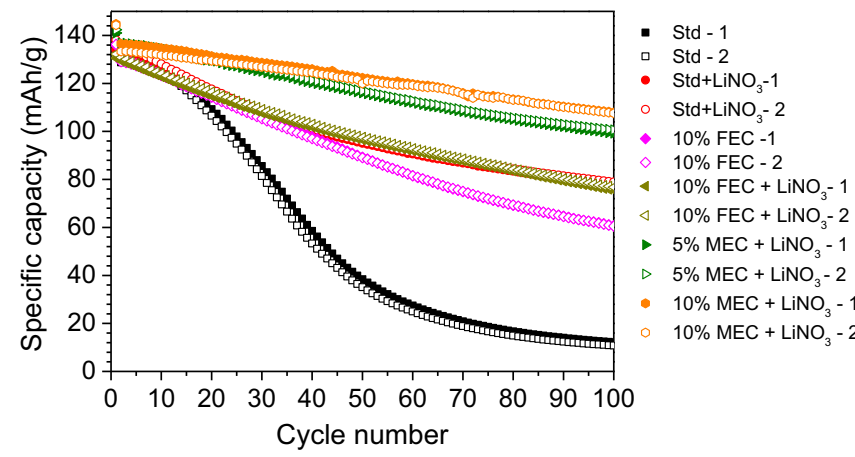

Figure 5. Specific capacity of Si-graphite/NCM111 full cells with different electrolytes. 
Table III. First discharge capacity, first cycle efficiency and capacity retention (average of duplicate cells) of Si-graphite/NCM111 full cells. Capacity retention was calculated compared to the $2^{\text {nd }}$ discharge capacity of the cells where the cells were cycled at same rate, $\mathrm{C} / 3$, for cycles 2-100.

First discharge capacity $(\mathrm{mAh} / \mathrm{g})$ First cycle Efficiency (\%) $100^{\text {th }}$ capacity retention $\left(\%\right.$, calculated against $2^{\text {nd }}$ discharge $)$

\begin{tabular}{cccc}
\hline Std & 142 & 83.1 & 8.8 \\
Std+LiNO & 138 & 82.4 & 57.6 \\
$10 \% \mathrm{FEC}$ & 136 & 80.0 & 44.6 \\
$10 \% \mathrm{FEC}+\mathrm{LiNO}_{3}$ & 130 & 77.0 & 57.9 \\
$5 \% \mathrm{MEC}+\mathrm{LiNO}_{3}$ & 141 & 84.0 & 73.3 \\
$10 \%{\mathrm{MEC}+\mathrm{LiNO}_{3}}^{10}$ & 145 & 86.0 & 79.9
\end{tabular}

other, dominated by $\mathrm{Li}_{2} \mathrm{CO}_{3}$ at 1490 and $869 \mathrm{~cm}^{-1}$ with a low concentrations of lithium carboxylate at $1613 \mathrm{~cm}^{-1}$ and poly(FEC) at $1802 \mathrm{~cm}^{-1}$. Overall, the IR spectra of the Si-graphite anode in full cells are slightly different from those cycled in half cells. Higher concentrations of $\mathrm{Li}_{2} \mathrm{CO}_{3}$ and lower concentration of poly(MEC) or poly(FEC) are observed for electrodes cycled in full cells.

High resolution $\mathrm{C} 1 \mathrm{~s}, \mathrm{O} 1 \mathrm{~s}, \mathrm{P} 2 \mathrm{p}$ and N1s XPS spectra of fresh and cycled electrodes are provided in Figure 7. The relative atomic concentrations for the surface of the cycled electrodes are also provided. The C1s spectrum of the fresh Si-graphite electrode contains a strong peak at $284.5 \mathrm{eV}$ from graphite. Peaks at $285 \mathrm{eV}$ and $289 \mathrm{eV}$ are attributed to hydrocarbon and $-\mathrm{COOH} / \mathrm{COOLi}$ groups, respectively, from the PAALi binder. The O1s spectrum of the fresh electrode has a broad peak at $531.5 \mathrm{eV}$ characteristic of $\mathrm{C}=\mathrm{O}$ and $\sim 533 \mathrm{eV}$ assigned to a mixture of Si-O and C-O. ${ }^{27,37-39}$ After cycling, the C1s spectrum of the electrode cycled with standard electrolyte has new peaks at 290 and $286.5 \mathrm{eV}$, and related peaks are observed in the $\mathrm{O} 1 \mathrm{~s}$ spectrum at 531.5 and $533 \mathrm{eV}$ characteristic of ROCOOLi and $\mathrm{Li}_{2} \mathrm{CO}_{3}{ }^{15,38}$ The electrode cycled with electrolyte containing added

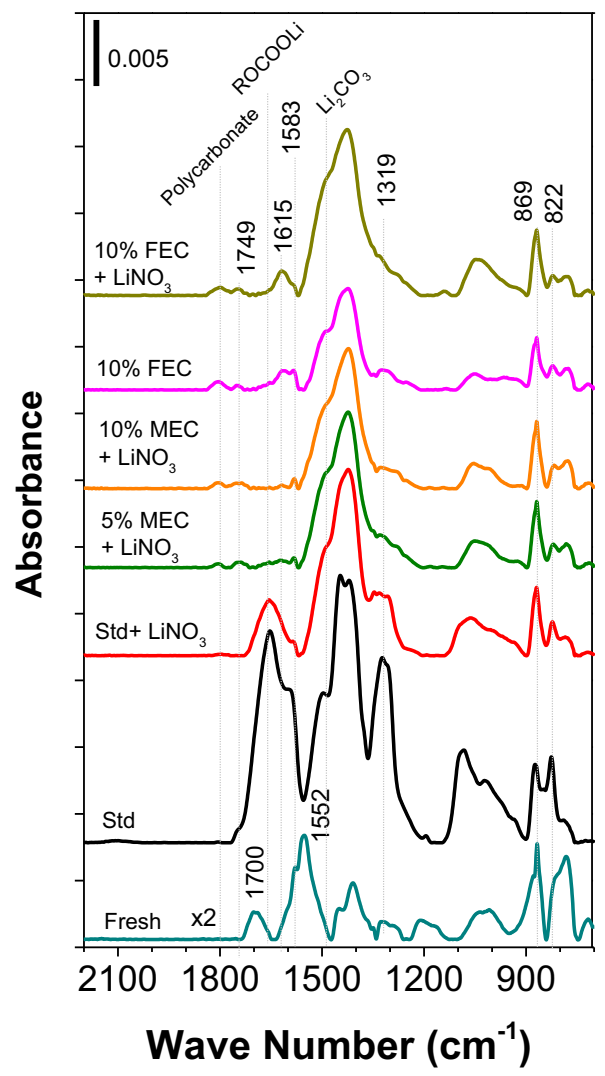

Figure 6. ATR-IR of Si-graphite anodes extracted from Si-graphite/NCM111 cells after 100 cycles.
$\mathrm{LiNO}_{3}$ has an increase in peak intensity at $290 \mathrm{eV}$ in $\mathrm{C} 1 \mathrm{~s}$ spectrum and $531.5 \mathrm{eV}$ in $\mathrm{O} 1 \mathrm{~s}$ spectrum, indicating an increase in the concentration of ROCOOLi or $\mathrm{Li}_{2} \mathrm{CO}_{3}$. The electrodes cycled with electrolyte containing $5 \% \mathrm{MEC}+\mathrm{LiNO}_{3}$ contain a small new peak at $291 \mathrm{eV}$ and an increase in peak intensity at $286.5 \mathrm{eV}$ in $\mathrm{C} 1 \mathrm{~s}$ characteristic of poly(MEC). This is further supported by the appearance of the peak at $534 \mathrm{eV}$ in the $\mathrm{O} 1 \mathrm{~s}$ spectrum. ${ }^{19,29}$ Increasing the concentration of MEC, $10 \% \mathrm{MEC}+\mathrm{LiNO}_{3}$, results in an increase in the intensity of the peaks at $291 \mathrm{eV}$ in $\mathrm{C} 1 \mathrm{~s}$ and $534 \mathrm{eV}$ in $\mathrm{O} 1 \mathrm{~s}$, consistent with an increase in the content of poly(MEC). The XPS and IR data suggest that the Si-graphite electrode is covered by $\mathrm{Li}_{2} \mathrm{CO}_{3}$ rich inner layer and poly(MEC) rich outer layer, since the IR spectrum, which has a greater depth of penetration, has greater relative intensity of the $\mathrm{Li}_{2} \mathrm{CO}_{3}$ peak while the XPS spectrum, which has a lower depth of penetration, has a greater relative intensity of the poly(MEC) peak. The electrode cycled with electrolyte containing 10\% FEC has similar spectral features to the electrode cycled with electrolyte containing $\mathrm{MEC}+\mathrm{LiNO}_{3}$, but the peaks for ROCOOLi and $\mathrm{Li}_{2} \mathrm{CO}_{3}$ at $\sim 290 \mathrm{eV}$ in $\mathrm{C} 1 \mathrm{~s}$ and $531.8 \mathrm{eV}$ in $\mathrm{O} 1 \mathrm{~s}$ have greater intensity.

The F1s spectra of the electrodes cycled with all of the electrolytes contain two peaks at 685 and $686.8 \mathrm{eV}$ characteristic of $\mathrm{LiF}$ and $\mathrm{Li}_{x} \mathrm{PO}_{y} \mathrm{~F}_{\mathrm{z}}$, respectively, from the decomposition of $\mathrm{LiPF}_{6}$. However, the intensity varies with the electrolyte composition. ${ }^{15,40}$ The electrodes cycled with added $\mathrm{LiNO}_{3}$ or $\mathrm{MEC}+\mathrm{LiNO}_{3}$ have weaker F1s peak intensity compared to the standard electrolyte consistent with a suppression of $\mathrm{LiPF}_{6}$ decomposition. Alternatively, the electrodes cycled with FEC containing electrolyte have higher concentrations of $\mathrm{F} 1 \mathrm{~s}$ peaks due to the generation of $\mathrm{LiF}$ from the reduction of FEC. . $^{15,41-43}$

The electrodes cycled with $\mathrm{LiNO}_{3}$-containing electrolytes have a peak at $407.5 \mathrm{eV}$ in the $\mathrm{N} 1 \mathrm{~s}$ spectrum from residual $\mathrm{LiNO}_{3}$. The presence of $\mathrm{LiNO}_{3}$ on the surface of the electrodes is likely due to the low solubility of $\mathrm{LiNO}_{3}$ in DMC, the solvent used for rinsing. A new small peak is observed at $403.5 \mathrm{eV}$ consistent with the presence of $\mathrm{LiNO}_{2}$ or $\mathrm{RNO}_{2}(\mathrm{R}=$ alkyl group) generated from the reduction of $\mathrm{LiNO}_{3}$. A broad strong peak centered at $400 \mathrm{eV}$ is observed characteristic of amine/ammonium salt, $\mathrm{R}_{3} \mathrm{~N} / \mathrm{R}_{4} \mathrm{~N}^{+}$. The electrode cycled with the std $+\mathrm{LiNO}_{3}$ electrolyte has a weaker N1s signal than electrodes cycled with the $\mathrm{MEC}+\mathrm{LiNO}_{3}$ or $\mathrm{FEC}+\mathrm{LiNO}_{3}$ electrolytes.

Surface chemistry of the cathode.-The IR-ATR spectra of NCM111 cathodes before and after 100 cycles are presented in Figure 8. The IR spectrum of fresh NCM111 cathode is dominated by signals from the PVDF binder at $1402,1175,878$ and $840 \mathrm{~cm}^{-1}$. ${ }^{44}$ A weak absorbance at $1489 \mathrm{~cm}^{-1}$ is from $\mathrm{Li}_{2} \mathrm{CO}_{3}$, a common surface impurity from metal oxide production. ${ }^{45,46}$ The electrode cycled with the standard electrolyte contains a weak peak at $1615 \mathrm{~cm}^{-1}$ attributed to lithium carboxylates and a strong peak at $1743 \mathrm{~cm}^{-1}$, from polycarbonate. The high concentration of polycarbonate is frequently observed when the cathode is cycled to potentials above $4.3 \mathrm{~V} .{ }^{38,39}$ While the cells investigated were only cycled to $4.2 \mathrm{~V}$, upon cycling full cells with $\mathrm{Si}$ electrodes the voltage of cathode shifts to higher voltage with increased cycles due to the continuous loss of active lithium. ${ }^{48,49}$ Since the Si-graphite/NCM111 cells cycled with standard electrolyte have severe capacity loss, the voltage of the cathodes should increase resulting in the formation of poly(EC). Incorporation of additives significantly 


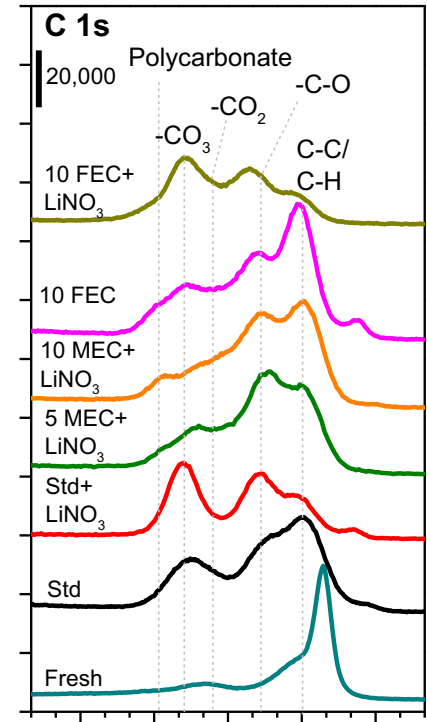

294291288285282

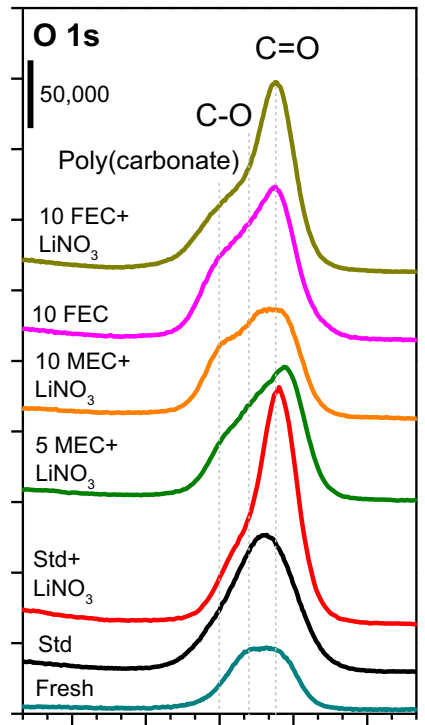

$\begin{array}{lllll}540 & 537 & 534 & 531 & 528\end{array}$

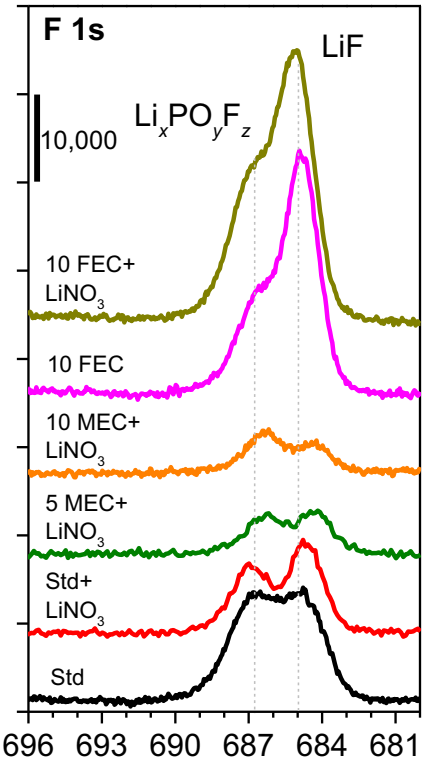

Binding Energy (eV)

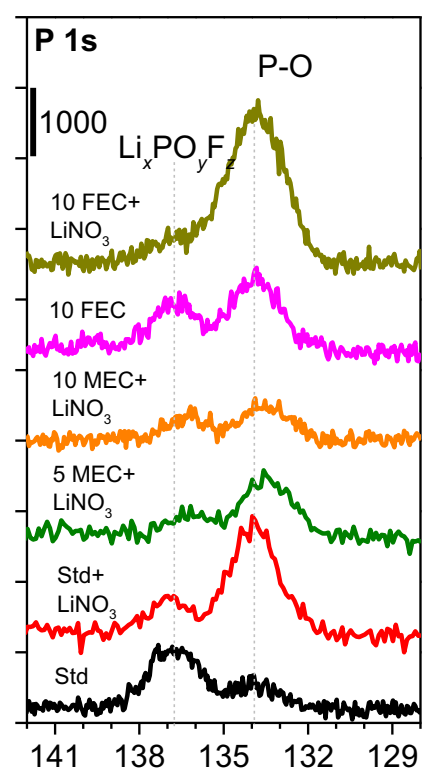

Binding Energy (eV)

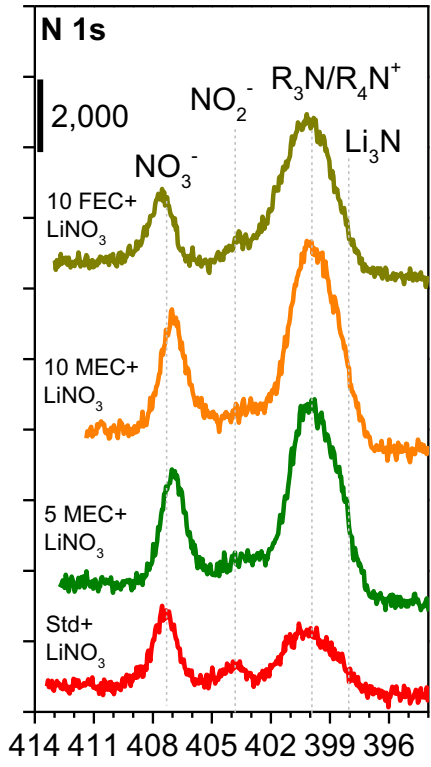

Binding Energy (eV)

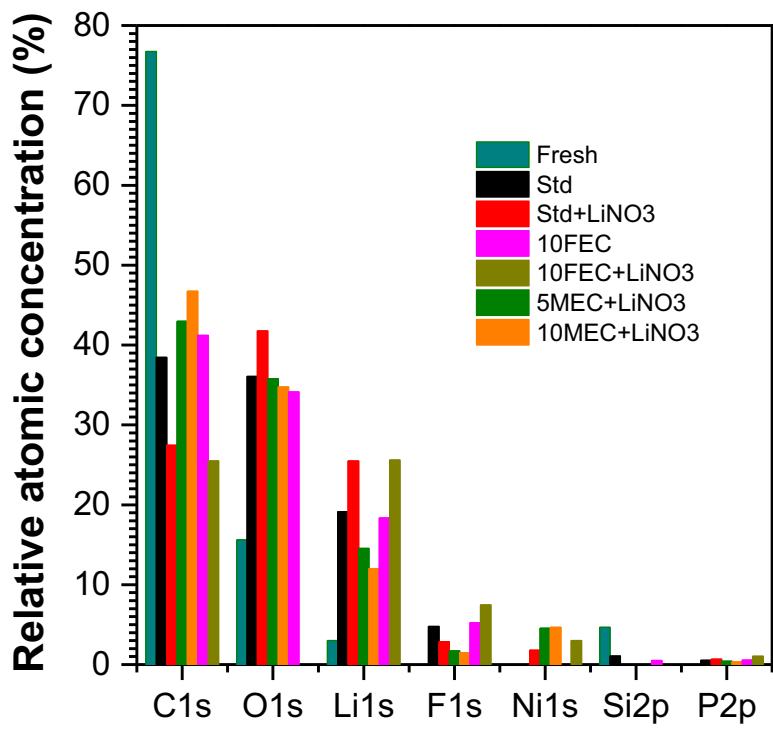

Elements

Figure 7. High resolution XPS spectra for C 1s, O 1s, F 1s, and N1s and relative atomic concentration of Si-graphite anodes extracted from Si-graphite/NCM111 full cells after 100 cycles.

reduces the intensity of the polycarbonate peak, consistent with stabilization of the cathode potential and improved capacity retention. In addition, the spectra of electrodes cycled with electrolyte additives are very similar to the fresh electrodes, suggesting minimal decomposition of the electrolyte on the cathode surface. Electrodes cycled with added MEC and $\mathrm{LiNO}_{3}$ contain a new weak peak at $1812 \mathrm{~cm}^{-1}$ from poly(MEC).

High resolution XPS spectra of fresh and cycled NMC111 cathodes are provided in Figure 9. The $\mathrm{C} 1$ spectrum of the fresh electrode contains strong peaks at 291 and $286.5 \mathrm{eV}$ in $\mathrm{C} 1 \mathrm{~s}$ characteristic of $-\mathrm{CF}_{2}-$ and $-\mathrm{CH}_{2}-$, respectively, from PVdF while the peak at $284.5 \mathrm{eV}$ is assigned to carbon black. After cycling, the C1s spectra of the cycled electrodes remain similar to the fresh electrodes for all electrolytes consistent with the presence of minimal electrolyte decomposition products. The $\mathrm{O} 1 \mathrm{~s}$ spectrum of the fresh electrode contains two peaks, one characteristic of the metal oxide (M-O) at
$529.5 \mathrm{eV}$ and a second at $531.8 \mathrm{eV}$ characteristic of $\mathrm{Li}_{2} \mathrm{CO}_{3}$, consistent with IR data. The M-O peak becomes weaker after cycling, consistent with the generation of a thin film composed of electrolyte decomposition products. The new peaks at 532 and $534 \mathrm{eV}$ are characteristic of the $\mathrm{C}=\mathrm{O}$ and $\mathrm{C}-\mathrm{O}$ of polycarbonate.

The $\mathrm{N} 1 \mathrm{~s}$ spectra of the cathodes cycled with electrolytes containing $\mathrm{LiNO}_{3}$ contain similar $\mathrm{N}$-containing species to the anodes cycled with electrolytes containing $\mathrm{LiNO}_{3}$, but the intensity of the peaks are much weaker on the cathodes. A very weak peak is observed at $408 \mathrm{eV}$, characteristic of residual $\mathrm{LiNO}_{3}$. The broad peak at $\sim 400 \mathrm{eV}$ is assigned to a combination of $\mathrm{R}_{3} \mathrm{~N} / \mathrm{R}_{4} \mathrm{~N}^{+}$. The presence of the $\mathrm{N}$ containing species on the cathode could result from either decomposition on the cathode or reduction on the anode followed by dissolution and deposition on the cathode.

The F1s spectra contain a strong peak at $688 \mathrm{eV}$ from the $-\mathrm{CF}_{2}-$ of PVdF. After cycling, a new weak peak is observed at $685 \mathrm{eV}$, 


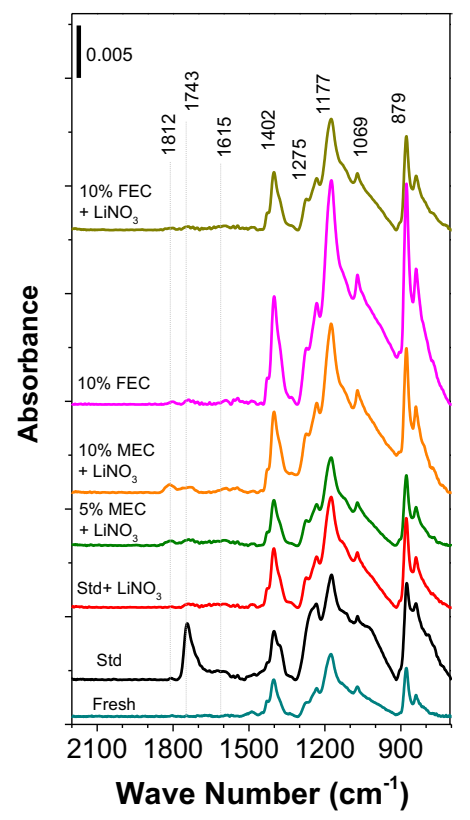

Figure 8. ATR-IR of NCM111 cathode extracted from Si-graphite/NCM111 cells after 100 cycles.

characteristic of LiF from the decomposition of $\mathrm{LiPF}_{6}$. The P2p spectra are similar for all electrodes and contain a very weak peak at $\sim 136 \mathrm{eV}$ characteristic of a low concentration of $\mathrm{Li}_{x} \mathrm{PF}_{y} \mathrm{O}_{z}$.

The data from IR and XPS on the anodes and cathodes reveal that the additives significantly modify the surface of the anode while changes to the surface of NCM111 cathodes are small. Thus, the improved electrochemical performance of the Si-graphite/NCM111 full cells upon addition of MEC and $\mathrm{LiNO}_{3}$ primarily results from the stabilization of the SEI on the Si-graphite anodes.

\section{Conclusions}

The performance of Si-graphite composite anodes have been investigated in Si-graphite/Li half cells and Si-graphite/NCM111 full cells with $1.2 \mathrm{M} \mathrm{LiPF}_{6} / \mathrm{EC}: \operatorname{DEC}(1 / 1, \mathrm{w} / \mathrm{w})$ electrolyte with a combination of FEC, MEC and $\mathrm{LiNO}_{3}$ as electrolyte additives. Incorporation of additives into the electrolyte results in a significant improvement of capacity retention compared to the standard electrolyte for Si-graphite/Li cells. Cells cycled with electrolyte containing $0.5 \% \mathrm{LiNO}_{3}, 5-10 \%$ MEC or $10 \%$ FEC have much better capacity retention, at least $89 \%$, compared to cells cycled with standard electrolyte, $\sim 64.0 \%$, after 100 cycles. The combination of $5-10 \%$ MEC with $0.5 \% \mathrm{LiNO}_{3}$ provides the best capacity retention, $\sim 93 \%$, after 100 cycles. Further investigations of Si-graphite/NCM111 cells reveal that the cells cycled with electrolyte containing $0.5 \% \mathrm{LiNO}_{3}$ have better capacity than cells cycled with electrolyte containing $10 \%$ FEC, $57.9 \%$ vs. $44.6 \%$, respectively. The combination of $10 \%$ MEC and $\mathrm{LiNO}_{3}$ further improves the capacity retention of the Si-graphite/NCM111 full cells to $79.9 \%$ after 100 cycles which is best among the electrolytes investigated. Ex-situ surface analysis of the electrodes via a combination of IR-ATR and XPS reveal significant changes to the SEI structure on Si-graphite anodes upon incorporation of the electrolyte additives. Addition of $\mathrm{LiNO}_{3}$ increases the concentration of $\mathrm{Li}_{2} \mathrm{CO}_{3}$ and decreases the concentration of lithium alkyl carbonates in the SEI while incorporation of MEC results in the generation of poly(MEC). Thus, an SEI composed of $\mathrm{Li}_{2} \mathrm{CO}_{3}$ and poly(MEC) appears to be particularly stable on the Si-graphite composite anode. Incorporation of the

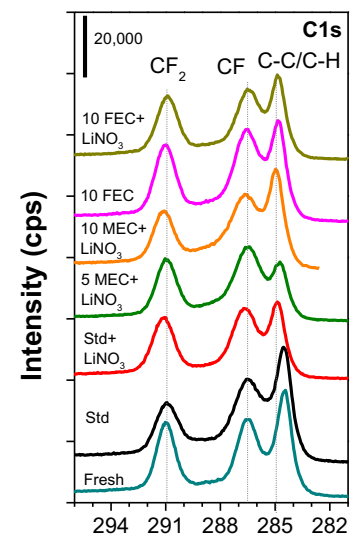

Binding Energy (eV)

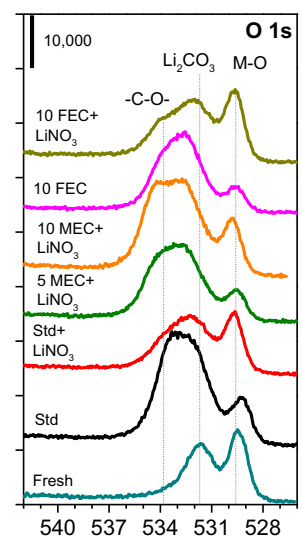

Binding Energy (eV)

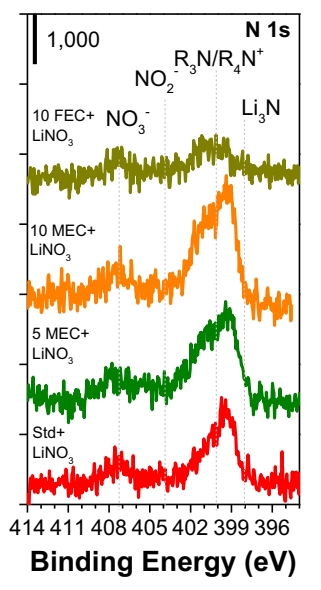

Binding Energy (eV)

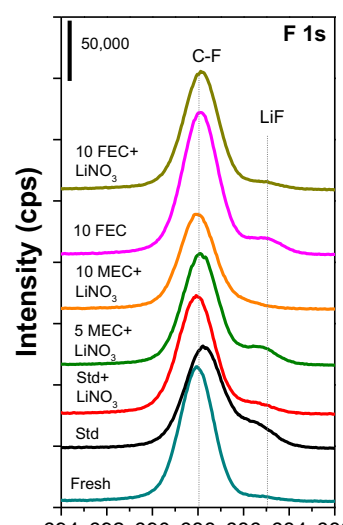

694692690688686684682

Binding Energy (eV)

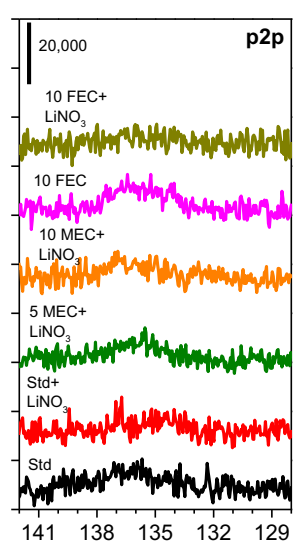

Binding Energy (eV)
Figure 9. High resolution XPS spectra for C 1s, O 1s, F 1s, and N1s and relative atomic concentration for NCM111 cathodes extracted from Si-graphite/NCM111 cells after 100 cycles. 
additives did not result in significant changes to the surface of the NMC111 cathode.

\section{Acknowledgments}

The authors gratefully acknowledge funding from Department of Energy Office of Basic Energy Sciences EPSCoR Implementation award (DE-SC0007074).

\section{ORCID}

Brett L. Lucht (D https://orcid.org/0000-0002-4660-0840

\section{References}

1. M. N. Obrovac and L. J. Krause, J. Electrochem. Soc., 154, A103 (2007)

2. M. N. Obrovac and V. L. Chevrier, Chem. Rev., 114, 11444 (2014).

3. M. T. McDowell, S. W. Lee, W. D. Nix, and Y. Cui, Adv. Mater, 25(36), 4966 (2013).

4. A. Magasinski, P. Dixon, B. Hertzberg, A. Kvit, J. Ayala, and G. Yushin, Nat. Mater. 9, 353 (2010).

5. C. K. Chan, H. Peng, G. Liu, K. McIlwrath, X. F. Zhang, R. A. Huggins, and Y. Cui, Nat. Nanotechnol., 3, 31 (2007).

6. J. H. Ryu, J. W. Kim, Y.-E. Sung, and S. M. Oh, Electrochem. Solid-State Lett., 7, A306 (2004).

7. N.-S. Choi, K. H. Yew, K. Y. Lee, M. Sung, H. Kim, and S.-S. Kim, J. Power Sources, 161, 1254 (2006)

8. M. Nie, D. P. Abraham, D. M. Seo, Y. Chen, A. Bose, B. L. Lucht, and D. Chalasani, J. Phys. Chem. C, 117, 13403 (2013).

9. C. C. Nguyen and B. L. Lucht, J. Electrochem. Soc., 161, A1933 (2014).

10. R. Petibon, V. L. Chevrier, C. P. Aiken, D. S. Hall, S. R. Hyatt, R. Shunmugasundaram, and J. R. Dahn, J. Electrochem. Soc., 163, A1146 (2016).

11. R. Jung, M. Metzger, D. Haering, S. Solchenbach, C. Marino, N. Tsiouvaras, C. Stinner, and H. A. Gasteiger, J. Electrochem. Soc., 163, A1705 (2016).

12. H. Kim, B. Han, J. Choo, and J. Cho, Angew. Chem. Int. Ed Engl., 47, 10151 (2008).

13. Z. Du, R. a. Dunlap, and M. N. Obrovac, J. Electrochem. Soc., 161, A1698 (2014).

14. V. L. Chevrier, L. Liu, D. B. Le, J. Lund, B. Molla, K. Reimer, L. J. Krause, L. D. Jensen, E. Figgemeier, and K. W. Eberman, J. Electrochem. Soc., 161, A783 (2014).

15. V. Etacheri, O. Haik, Y. Goffer, G. A. Roberts, I. C. Stefan, R. Fasching, and D. Aurbach, Langmuir, 28, 965 (2011).

16. L. Ma, J. Xia, X. Xia, and J. R. Dahn, J. Electrochem. Soc., 161, A1495 (2014)

17. D. Y. Wang, N. N. Sinha, J. C. Burns, C. P. Aiken, R. Petibon, and J. R. Dahn, J. Electrochem. Soc., 161, A467 (2014).

18. K. Kim, I. Park, S.-Y. Ha, Y. Kim, M.-H. Woo, M.-H. Jeong, W. C. Shin, M. Ue S. Y. Hong, and N.-S. Choi, Electrochimica Acta, 225, 358 (2017).

19. C. C. Nguyen and B. L. Lucht, Electrochem. Commun., 66, 71 (2016).
20. D. Aurbach, E. Pollak, R. Elazari, G. Salitra, C. S. Kelley, and J. Affinito, J. Elec trochem. Soc., 156, A694 (2009).

21. S. S. Zhang, J. Power Sources, 322, 99 (2016).

22. A. Rosenman, R. Elazari, G. Salitra, E. Markevich, D. Aurbach, and A. Garsuch, $J$. Electrochem. Soc., 162, A470 (2015).

23. F. C. de Godoi, D.-W. Wang, Q. Zeng, K.-H. Wu, and I. R. Gentle, J. Power Sources, 288, 13 (2015).

24. S. Xiong, K. Xie, Y. Diao, and X. Hong, Electrochimica Acta, 83, 78 (2012).

25. X. Liang, Z. Wen, Y. Liu, M. Wu, J. Jin, H. Zhang, and X. Wu, J. Power Sources, 196, 9839 (2011).

26. V. Etacheri, U. Geiger, Y. Gofer, G. A. Roberts, I. C. Stefan, R. Fasching, and D. Aurbach, Langmuir, 28, 6175 (2012)

27. C. C. Nguyen, T. Yoon, D. M. Seo, P. Guduru, and B. L. Lucht, ACS Appl. Mater. Interfaces, 8(19), 12211 (2016).

28. X. Zhang, R. Kostecki, T. J. Richardson, J. K. Pugh, and P. N. Ross, J. Electrochem. Soc., 148, A1341 (2001).

29. D. Chalasani, J. Li, N. M. Jackson, M. Payne, and B. L. Lucht, J. Power Sources, 208, 67 (2012).

30. S. S. Zhang, J. Electrochem. Soc., 159, A920 (2012).

31. S. Tsubouchi, Y. Domi, T. Doi, M. Ochida, H. Nakagawa, T. Yamanaka, T. Abe, and Z. Ogumi, J. Electrochem. Soc., 159, A1786 (2012).

32. R. A. Friedel and G. L. Carlson, J. Phys. Chem., 75, 1149 (1971)

33. K. Xu, G. V. Zhuang, J. L. Allen, U. Lee, S. S. Zhang, P. N. Ross, and T. R. Jow, J Phys. Chem. B, 110, 7708 (2006)

34. D. Aurbach and B. Markovsky, J. Electrochem. Soc., 143, 3809 (1996)

35. H. Ota, Y. Sakata, A. Inoue, and S. Yamaguchi, J. Electrochem. Soc., 151, A1659 (2004).

36. A. Michan, B. Parimalam, M. Leskes, R. Kerber, T. Yoon, C. Grey, and B. L. Lucht, Chem. Mater., 28, 8149 (2016).

37. T. P. Nguyen and S. Lefrant, J. Phys. Condens. Matter, 1, 5197 (1989).

38. R. Dedryvère, L. Gireaud, S. Grugeon, S. Laruelle, J.-M. M. Tarascon, D. Gonbeau, and R. Dedryvere, J. Phys. Chem. B, 109, 15868 (2005)

39. B. Philippe, R. Dedryvère, J. Allouche, F. Lindgren, M. Gorgoi, H. Rensmo, D. Gonbeau, and K. Edström, Chem. Mater., 24, 1107 (2012).

40. A. M. Andersson, M. Herstedt, A. G. Bishop, and K. Edström, Electrochimica Acta, 47, 1885 (2002)

41. K. Leung, S. B. Rempe, M. E. Foster, Y. Ma, J. M. M. del la Hoz, N. Sai, and P. B. Balbuena, J. Electrochem. Soc., 161, A213 (2014).

42. I. A. Shkrob, J. F. Wishart, and D. P. Abraham, J. Phys. Chem. C, 119, 14954 (2015)

43. B. T. Young, D. R. Heskett, C. C. Nguyen, M. Nie, J. C. Woicik, and B. L. Lucht, ACS Appl. Mater. Interfaces, 7, 20004 (2015).

44. Y. Bormashenko, R. Pogreb, O. Stanevsky, and E. Bormashenko, Polym. Test., 23 791 (2004).

45. G. V. Zhuang, G. Chen, J. Shim, X. Song, P. N. Ross, and T. J. Richardson, J. Power Sources, 134, 293 (2004).

46. L. Yang, B. Ravdel, and B. L. Lucht, Electrochem. Solid-State Lett., 13, A95 (2010)

47. T. Liu, A. Garsuch, F. Chesneau, and B. L. Lucht, J. Power Sources, 269, 920 (2014)

48. S. D. Beattie, M. J. Loveridge, M. J. Lain, S. Ferrari, B. J. Polzin, R. Bhagat, and R. Dashwood, J. Power Sources, 302, 426 (2016).

49. M. Klett, J. A. Gilbert, S. E. Trask, B. J. Polzin, A. N. Jansen, D. W. Dees, and D. P. Abraham, J. Electrochem. Soc., 163, A875 (2016). 